\title{
Research
}

\section{Empirical Accounting of Adaptation to Environmental Change: Organizational Competencies and Biodiversity in Finnish Forest Management}

\author{
$\underline{\text { Eeva Primmer }}^{1}$ and Steven A. Wolf ${ }^{2}$
}

\begin{abstract}
Integration of biodiversity conservation into economic utilization of natural resources has become a central response to the challenges of sustainable development. However, the resources and competencies required to implement such an integrated strategy at the level of the individual, the organization, and the sector are not known. To address this knowledge gap, we have developed an approach to analyze responses of organizations to environmental change and evolving social demands for biodiversity conservation. We analyze the scale, scope, and distribution of the resources and competencies that support the delineation of ecologically significant habitats in intensively managed nonindustrial private forests in Finland, an important international actor in the sector. Based on a national survey of 311 foresters working in public agencies, private firms, and cooperative organizations, we investigate the division of labor in the sector and the patterns of investment in human capital, organizational resources, and information networks that support delineation. We find that communicating frequently with the actors who are directly engaged in field operations is consistently the most productive resource in conserving habitats. Our analysis identifies differences in competencies among different types of organizations, as well as distinct roles for public and private-sector organizations. Beyond identification of differences in conservation behavior and competencies among organizations, our analysis points to substantial uniformity in the sector. We attribute similarities in patterns of investment in conservation resources to historically structured central coordination mechanisms within the sector that include education, training, and broadly shared professional norms. These institutional structures and the resulting uniformity can be potential impediments to radical innovation. Our approach to analyzing adaptation to environmental change highlights the interplay between investments in competencies by actors within a particular technical domain and the evolving external institutional environment.
\end{abstract}

Key Words: Competency; organization; innovation; nonindustrial private forestry; biodiversity conservation; habitat delineation; resource-based view; institutions; Finland;

\section{INTRODUCTION}

In terms of both policy and practice, the challenge of sustainable development lies in the integration of ecological considerations into production and consumption. Applied to forest management, there is a growing perception that ecological integrity and, more specifically, biodiversity cannot be successfully maintained solely by taking land out of production (Hartley 2002, Lindenmayer and Franklin 2002, Millennium Ecosystem Assessment 2005). Political and budgetary constraints as well as the dependence of some rural regions on natural resource extraction have made the expansion of parks and wilderness areas increasingly unattractive in some settings (Brechin et al. 2003). Limits on conservation strategies premised on differentiating protected areas from zones of exploitation have served to increase the relevance of strategies aimed at generating ecological benefits from privately owned, actively managed forest tracts (McCarthy 2005). This multifunctional approach to protecting biodiversity specifically demands the integration of production and conservation functions on the portion of the landscape exploited for economic purposes (Klein and Wolf 2007). 
Environmental change is both a product of social and technical change and a driver and context for continued adaptation. Understanding this coevolutionary dynamic and developing practical insights aimed at enhancing the feedbacks on which system-level stability and resilience depend represent important challenges on the research frontier (Norgaard 1994). The forest sector has been dealing with the issue of sustainability at the levels of research, policy, and operations for several decades (Farrell et al. 2000). Contemporary concerns regarding biodiversity have subsumed and eclipsed traditional conservation targets such as water resources and wildlife. Silvicultural techniques and standards aimed at a deeper integration of conservation and management objectives have been identified to advance ecological sustainability (Graham and Jain 1998, Hartley 2002, Lindenmayer and Franklin 2002). These include using native tree species and long rotation times, leaving corridors between patches and retention trees on logging sites, and conserving valuable habitats. Habitat conservation is a particularly essential conservation practice because sensitive and specialized species are dependent on particular conditions (Pimm et al. 1995, Lindenmayer and Franklin 2002, Pykälä 2004). Although the goal of ecologically sustainable forest management is politically well established (Millennium Ecosystem Assessment 2005), knowledge regarding the responses of practitioners, i.e., the manner in which commitments to conservation and sustainability have been operationalized by professionals and the organizations in which they work, is scarce.

There is tremendous interest in adaptive management, learning, and innovation in support of sustainability. Interactive and relational theories of knowledge production now complement the earlier emphasis on the linear model of innovation and its focus on information dissemination and technology transfer (Rosenberg 1982). Currently, analysis of adaptation is centered on the interfaces between biophysical and socioeconomic subsystems, particularly on understanding modes of response to complex and abrupt, i.e., nonlinear, problems (Campbell et al. 2001, Holling 2001, Folke et al. 2005). Adaptation is seen as largely dependent on social learning. Within this academic tradition, there is a high appreciation of participation, trust building, and deliberative competence in keeping with contemporary notions of governance (Lebel et al. 2006, Tàbara and Pahl-Wostl 2007, Armitage et al.
2008). Although potentially valuable, these approaches to understanding and supporting adaptation do not speak directly to the technical character of natural resource management as practiced by the professionals and organizations that must perform complex tasks in variable settings. Research on the construction of new modes of technical practice in natural resource conservation and management is sparse. The scale, scope, and distribution of investments are not known.

Learning to produce ecological benefits while maintaining socioeconomic competitiveness demands the development of new material practices. These practices are outcomes of innovation processes and organizational knowledge creation (March 1999). To understand the development of operational practices, attention needs to be paid to the competencies that actors develop and apply in responding to natural resource management challenges (Wolf and Primmer 2006). Competencies derive from resources that organizations mobilize to maintain legitimacy (Cyert and March 1992) and to fulfill their missions and compete (Nelson and Winter 1982). At the societal or population level, the uneven distribution of productive resources including skilled workers, appropriate management systems, and linkages to outside expertise gives rise to locally differentiated costs and opportunities for developing new competencies within organizations (Nelson 1991). With this in mind, we expect significant variation in stocks and flows of conservation competencies among actors in the Finnish forest sector, a sector confronting a rapidly evolving social demand for environmental quality and ecological services (Wolf and Primmer 2006). Within evolutionary accounts of economic systems, variation in competencies and idiosyncrasies in how resources are combined and used at the level of individual organizations is an essential driver for innovation and adaptation at the level of a population of organizations. Diversity creates opportunities for selection pressures, i.e., market mechanisms and accountability regimes, to operate and, through selection, the population can evolve.

The resource- or competency-based view of organizations and economic processes has been developed as a counterpoint to the traditional economic framework that relies on external conditions to explain organizational behavior and performance (Nelson and Winter 1982, Barney 1991, Nelson 1991). When confronted with legitimacy challenges and competition, actors 
mobilize resources in response to the demand for products or services (Nelson 1991, Simon 1997). Hart (1995), Rugman and Verbeke (1998), and Sharma and Vredenburg (1998) have analyzed organizational resources to assess how firms position themselves with respect to environmental challenges and opportunities. Investing in improved environmental performance has been shown to be a potentially successful enterprise strategy (Porter and van der Linde 1995, Russo and Fouts 1997, Sharma and Vredenburg 1998, Menguc and Ozanne 2005), particularly in cases in which organizations have made complementary investments in productivity-enhancing innovations and learning (Christmann 2000, Judge and Elenkov 2005).

We identify three generic categories of resources relevant to our analysis: human capital, organizational routines, and status in networks (Wolf and Primmer 2006). To carry out their core tasks and develop strategically important activities, including environmental management functions, organizations require educated, experienced, and skilled labor (Lado and Wilson 1994). Human capital contributing to biodiversity conservation includes formal education, skills acquired through specialized training, and experience in various settings. Second, organizations require resources for coordination (Cyert and March 1992, Zander and Kogut 1995). Organizational management systems translate general strategies into routine decisions (Nelson and Winter 1982, Lado and Wilson 1994, Chandler 1997) and allow the organizational strategy to be reflected in the individual worker's practice (Cyert and March 1992, Zollo and Winter 2002). Translation and coordination resources include operational guidelines, information management systems and technology, administrative hierarchies, auditing controls, and participatory planning procedures. Third, organizations derive resources through social, professional, and information networks to a varying degree (Ritter and Gemünden 2003, Just et al. 2006). Applied to biodiversity conservation in forestry, these external linkages can take the form of connections with private and public actors upstream and downstream in value chains. Additionally, connections can be horizontal links that connect peers occupying similar professional and functional positions.

Although theoretical and empirical applications of the resource-based view have focused almost exclusively on firms and industrial sectors of interest to business management scholars, i.e., core industries and the new information economy, the concepts are highly relevant to contemporary natural resource management settings. Given the expanding pace and significance of environmental change, public and private sector organizations need to increasingly reflect on the resources available to them to mitigate and adapt to these changes.

To assess adaptation to new accountability requirements and to advance research on organizational learning for sustainability, we analyze mobilization of resources by natural resource professionals responsible for conserving ecologically significant habitats. Because the conservation of habitats is dependent on their identification and delineation in the field, success rests on the people and organizations that plan and conduct forestry operations in nonindustrial private forests. We identify four categories of relevant organizations whose foresters plan management operations in nonindustrial private forests: public sector organizations (regional forestry centers); private sector organizations (large-scale industry and small-scale entrepreneurs); and local cooperatives (local forest management associations). See Appendix 1 for details on the organizational context of habitat conservation in Finland. Based on a national survey of forestry professionals conducted in 2006, we identify the division of labor underlying conservation of habitats in Finnish forestry and assess the relative contributions of organizational resources to habitat conservation. Our empirical analysis is structured by the following questions:

1. Which resources are mobilized in habitat conservation?

2. How do conservation and patterns of investment in resources differ across actors, and what does this tell us about the division of labor in the sector?

3. Which resources contribute most significantly to habitat conservation?

Our aim is to improve the understanding of competency formation and the underlying patterns of (re)allocation of resources by organizations confronting environmental change. In the following section of the paper, we describe biodiversity conservation in the management of nonindustrial private forests in Finland. After describing our data 
collection and analysis methods, we present and discuss our findings.

\section{BIODIVERSITY CONSERVATION IN FINNISH FOREST MANAGEMENT}

Biodiversity conservation in Finnish nonindustrial private forestry provides a useful context for exploring responses to the challenge of integrating ecological and economic objectives. Forests are the most common and most species-rich habitat type in Finland, and they host a large share of the country's threatened species. Forestry poses the primary threat for these species, because many of them dwell in managed forests (Auvinen et al. 2007). Most managed forests are controlled by nonindustrial private owners, who number more than half a million; they account for $60 \%$ or more than 12 million ha of forest land and produce close to $80 \%$ of all the domestic commercial wood supplied to industry. Nonindustrial private forestry produces close to $6 \%$ of Finland's GNP and provides 90,000 jobs (Finnish Forest Research Institute 2007). Furthermore, most of the population uses these same forests for recreation. Nonindustrial private forest ownership is particularly prevalent in southern Finland, where the human population is concentrated and where less than $2 \%$ of forest land is preserved in conservation areas (Finnish Forest Research Institute 2007). After years of heated political interactions, there is now an institutionalized commitment to securing nature conservation values from privately owned forests through a mixture of policy approaches including regulation, compensation, and provision of technical assistance as well as forest certification. The integration of nature conservation into silvicultural planning and operations has been a central element of the strategy to conserve biodiversity in Finland since the Forest Act of 1996.

In analyzing adaptation in Finnish forestry, it is important to recognize a long history of corporatist governance in which representatives of political and economic interest groups negotiate policies with representatives of the state (Ollonqvist 1998). These negotiations produce and perpetuate economic incentives, administrative rules, and highly professionalized extension and planning systems that in turn structure local production of timber and other goods and services from forests (Ollonqvist 1998, Hujala et al. 2007). Although recent decades have brought important changes, the principle dynamic has been one of continuity. Changes in markets, competition, regulation, technologies, demographics, and the socioeconomic status of forestry have given rise to more or less incremental adjustments. The sector has demonstrated an ability to internalize waves of change in a collectively organized and coordinated fashion and apply these changes in areas such as shaping silvicultural techniques, boosting harvests, and introducing sustainability criteria (Ollonqvist 1998). This professional and administrative coordination has contributed to institutional uniformity, i.e., a tendency for organizations to respond similarly to new challenges and thus undergo a process of convergence, or what DiMaggio and Powell (1983) have called "isomorphism."

To operationalize integration of biodiversity conservation into forest management, a number of technical changes have been made to the silvicultural rules and guidelines adopted by the Finnish forest sector. The most concrete commitment is to the delineation and conservation of small, ecologically valuable habitats as mandated by the 1996 Forest Act, which lists seven habitat types including small watercourses, herb-rich habitats, and barrens. To date, some 79,000 habitats have been identified as worthy of conservation on nonindustrial private lands (Finnish Forest Research Institute 2007). The habitats average 0.6 ha in size, although most are substantially smaller (Kotiaho and Selonen 2006). On these habitats, silvicultural operations such as harvesting and drainage are prohibited or significantly constrained. On average, $0.6 \%$ of the managed forest area is conserved under this legislative policy; the area varies from 0.3 to $1.5 \%$ among administrative regions. In addition to legislation, widely adopted eco-certification standards (FFCS 2003) and professional guidelines, i.e., voluntary codes of best practice (Tapio 2001), support the conservation of valuable habitats.

Although forest landowners are legally responsible for conserving habitats on their land, in practice the conservation of habitats depends on their identification and delineation by the professionals who plan forestry operations on behalf of the landowners. Planning and delineation are done in connection with either a $10-y r$ management plan designed to structure future forestry operations or as part of an operational plan for harvesting to be carried out immediately. Professionals who plan operations in nonindustrial private forests have the 
duty to identify and delineate Forest Act habitats, and they follow professional guidelines and certification standards. These standards apply to all organizations (see Appendix 1 for organizational context).

The degree to which these policies and norms shape contemporary practice is unclear. Pykälä (2007) has identified a general failure to conserve habitats in southern Finland by means of the empirical assessment of habitat characteristics and status. He attributes problems in the implementation of biodiversity conservation commitments partly to the failure of forestry actors to adapt and modernize their competencies. Pykälä's findings highlight challenges in learning, information management, and organizational change.

Mandatory conservation of specific classes of small habitats of ecological significance has emerged as the principle policy response to concerns regarding biodiversity conservation in commercially managed nonindustrial private forests in Finland. As a novel practice predicated on the integration of conservation behaviors into economic routines, habitat delineation serves as an ideal focus for investigating adaptation to environmental change by natural resource management organizations.

\section{MATERIALS AND METHODS}

\section{Sample and data collection}

We conducted a nationwide survey of a proportionate stratified random sample of Finnish foresters engaged in planning forestry operations and making long-term forest plans. We assembled comprehensive sample frames for each of the four organizational types discussed above, i.e., a total of 2160 forestry professionals. We selected $25 \%$ of these individuals at random from each of the four lists to receive questionnaires.

The survey was developed based on earlier qualitative empirical work on biodiversity conservation in Finnish forestry (Wolf and Primmer 2006, Auvinen et al. 2007). We pretested the survey with representative respondents and revised the framework based on feedback (Sudman et al. 1996). The survey was sent to 563 foresters in March 2006, with a reminder to nonrespondents 10 days later, and a second survey was sent to the remaining nonrespondents after another 10 days. The 311 usable responses represent an overall response rate of $58 \%$ (Table 1). Potential nonresponse bias was evaluated by conducting $t$ tests between responses received during the first wave of the survey and those that were returned following reminders. No statistically significant differences were identified, which suggests that our sample was not biased (Armstrong and Overton 1977).

\section{Variables}

To measure delineation output, we collected data on total area planned and the number of habitats the respondents delineated in the calendar year 2005. The number of habitats delineated is a proxy for volume of delineation because most habitats are smaller than 1 ha in size (mean 0.6 ha, median 0.35 ha; Kotiaho and Selonen 2006), and was therefore chosen as a dependent variable. Additionally, to control for differences in the scale of the respondents' planning activities, i.e., the area across which they might encounter habitats, we calculated a second dependent variable, habitat delineation rate. This second measure of delineation output, the number of habitats delineated divided by the total area planned, represents the frequency with which planners delineated habitats as part of their forestry planning function. There are regional differences in inventoried habitat density that, according to Kotiaho and Selonen (2006), are partly because of ecological differences and partly because of differences in habitat inventory procedures among regions. There are no data available at a fine geographic scale to assess the density of habitats, and for this reason we assume that the respondents had equal opportunity to come across habitats.

To analyze the resources that forest planners mobilized in conserving habitats, we collected detailed data on human capital, organizational resources, and information sourcing in networks. These variables are conceptualized as inputs in the conservation function, and we treat them as independent variables in our explanatory analysis.

\section{Measures of human capital}

We collected data on respondent education, biodiversity training, and experience. Education was measured on a five-point scale ranging from no vocational education to a master's degree. A summary variable of biodiversity training was 
Table 1. Responses from different strata.

\begin{tabular}{lcc}
\hline \hline Stratum & Response & Response $\%^{\circ}$ \\
\hline Regional forestry center forest planners $^{\dagger}$ & 55 & 60 \\
Local forest management association foresters $^{\ddagger}$ & 111 & 55 \\
Timber-purchasing foresters from forest industry companies $^{\S}$ & 132 & 62 \\
Forest service entrepreneurs & 13 & 41 \\
Overall & 311 & 58 \\
\hline
\end{tabular}

${ }^{\dagger}$ Names and addresses retrieved from the database of forestry center experts available on the Internet.

¥Contact details available on the Internet.

${ }^{\S}$ Based on information received from the three largest forest industry companies in Finland: Metsäliitto, Stora Enso, and UPM-Kymmene. Employees of Tornator, a forestry service company under Stora Enso, were contacted via the Internet. Fifty percent of Tornator was sampled because of the small size of the population in that stratum.

Enterprises that provide forestry services identified through the registery maintained by the Finnish forestry experts association.

constructed by tallying respondents' positive responses to (1) a national program for professional development called nature management training, (2) biodiversity training provided by their organizations, (3) biodiversity training outside their organizations, and (4) university-based forest ecology courses. Experience was measured in number of years working in forest management since the first degree.

\section{Measures of organizational resources}

We assessed organizational resources by collecting data on the presence or absence of tools, organizational practices, and working conditions used in habitat conservation. To account for both stocks and flows of competencies, we combined data on organizational resources in the present period $(0=$ No, $1=$ Yes $)$ with data on respondents' expectations for levels of organizational investment in these resources over the next two years (decline -0.5 , stay the same 0 , improve 0.5 ). Measures of present and future status were summed to create an integrated measure ranging between -0.5 and 1.5 .
Principal component analysis (PCA) allowed us to reduce the list of potentially important organizational resources into components that represent bundles or clusters of resources. PCA reduces a large number of variables into a small set of components that summarizes the correlations among the variables (Tabachnick and Fidell 2001). The resulting component scores illustrate the relative degree to which each respondent relied on each of these resource bundles.

The PCA with varimax rotation yielded six components (Eigenvalue > 1) that explained more than $67 \%$ of the variance. The results of the PCA pointed to the existence of varied resource endowments, management orientations, and coordination strategies in the sector. We labeled these organizational resource components as follows: (1) procedures, including management and information systems; (2) external coordination involving various external contacts; (3) internal coordination involving intra-organizational coordination systems; (4) support or assistance; (5) spatial tools such as maps and GIS; and (6) time and money. All scores are presented in Table A2-1 in Appendix 2. 
The component scores on organizational resources were used as independent variables in all analyses. In addition to these six components, we measured the level of organizational investment in environmental management systems on a 0-4 scale by counting how many of these four relevant certifications had been achieved: ISO (International Organization for Standardization) 14001, EMAS (Eco-Management and Audit Scheme), FFCS (Finnish Forestry Certification Council) 2003, and PEFC (Pan-European Forest Certification).

\section{Measures of information sourcing in networks}

Based on a five-point scale ranging from "never" to "always," we collected data on the frequency with which respondents obtained useful information regarding habitat delineation from 19 potential sources. These data were reduced through PCA, resulting in four components (Eigenvalue $>1$ ) that reflected the differentiated information sourcing patterns among the planners and explained more than $55 \%$ of the variance. There were four clearly differentiated components, or orientations to information sourcing, within the population (Table A2-2 in Appendix 2). We labeled these information sourcing orientations as follows: (1) public agencies, including authorities and formal sources; (2) forestry operations or actors involved in timber trade and extraction; (3) internal sources within one's own organization; and (4) forest administration, including forest sector agencies and official habitat inventories, to correspond with the four components.

\section{Analytical methods}

After examining the demographic characteristics of forest planners and their conservation practices, we conducted analyses of variance across the four organization types targeted in our survey to assess similarities and differences in relevant outputs, i.e., conservation behaviors, and inputs, i.e., human, organizational, and external resources. To further evaluate identified differences, we compared all competencies pairwise between organizations using a Bonferroni adjustment. We then went on to conduct regression analyses to examine the explanatory power of resources applied to the conservation of habitats in the entire population and within specific organization types. The dependent variables illustrating conservation behavior, i.e., habitat delineation and habitat delineation rate, were transformed logarithmically $(\log 10)$ to generate a normal distribution from right-skewed distributions.

\section{RESULTS}

\section{Descriptive statistics}

The respondents were predominantly male (92\%) and $46 \mathrm{yr}$ of age, on average. A vast majority of them lived in rural areas or in small villages or towns (83\%). Two thirds were forest owners themselves. In describing their professional roles, respondents generally reported engagement in two to four distinct tasks from a list of six presented in the survey. The most commonly reported tasks were silviculture operations and planning (55\%), extension (67\%), and biodiversity conservation $(68 \%)$. Of the 190 responses we received to an openended question regarding the respondents' role in biodiversity conservation, more than half indicated that conservation was done in connection with planning and/or marking forestry operations. Despite frequent identification of biodiversity conservation as a part of their job description, $90 \%$ of the respondents evaluated the proportion of working time allocated to biodiversity conservation to be less than $10 \%$; $40 \%$ reported allocating $0 \%$ of their time to biodiversity conservation.

The 311 respondents planned close to 200,000 ha during the year 2005. In this area they delineated 5833 habitats, of which they discovered 1576 on site. The average number of habitats delineated per planned hectare was 0.06 , i.e., the average planner delineated a habitat on every 18 th ha he/she planned. Most respondents were not very active in delineating habitats. Stated differently, a minority of the respondents accounted for most of the conservation activity. The typical respondent, illustrated by mode, planned 250 ha and delineated five habitats in 2005 (Table 2).

The respondents' resources were homogenous, broadly speaking. Levels of education and training were uniform, and there was little variance in organizational resources (Tables A3-1 and A3-2 in Appendix 3). The respondents had typically completed a technical degree, almost exclusively in the area of forestry. Based on 288 responses to an open-ended question regarding the specific titles of their academic degrees, 284 held forestry degrees. The typical respondent had completed three different types of biodiversity training courses and had 21 years of work experience. In general, respondents reported that their organizations had made investments in the tools and procedures we identified in the survey and their expectations were for these levels of investments to be maintained or, 
Table 2. Planning, habitat discovery, and habitat delineation in $2005(N=311)$.

\begin{tabular}{lccccccc}
\hline \hline Activity & Minimum & Maximum & Mean & Median & Mode & SD & Total \\
\hline Planning (ha) & 0 & 7000 & 599 & 250 & 250 & 911 & 186,383 \\
Habitat discovery on site (number) & 0 & 350 & 5.07 & 2.00 & 0.00 & 21.78 & 1576 \\
Habitat delineation (number) & 0 & 400 & 18.76 & 9.00 & 5.00 & 38.49 & 5833 \\
$\begin{array}{l}\text { Habitat delineation rate (no. delineated/ha } \\
\text { planned) }\end{array}$ & 0.00 & 0.93 & 0.06 & 0.03 & 0.00 & 0.09 & \\
\hline
\end{tabular}

in some cases, expanded. Improvements were expected particularly in spatial tools, whereas financial resources and time were expected to become more scarce. The most common sources of information used in biodiversity conservation tasks were forestry administration and forestry operations actors who had hands-on roles in making decisions, planning, and executing forestry operations in the field (Table A3-3 in Appendix 3).

The results of the PCA data reduction that we applied to organizational resources and information sourcing highlighted distinct patterns of investment and behavior within the population of natural resource management organizations. The contrasting structures, strategies, and networks pointed to different endowments and orientations, raising the question about whether reliance on some or a combination of these distinct resource bundles leads to higher or lower delineation outcomes.

\section{Role division}

To assess the functional division of labor and evaluate differences in conservation competencies among actors in forest management, we compared delineation behaviors and relevant resources of the four organization types in our study. Role division in habitat delineation was mainly because the planners at regional forestry centers (RFCs) planned larger areas. Given that habitats can be assumed to be relatively evenly distributed, the foresters working in these public agencies delineated the largest number of habitats (Table 3). Habitat delineation rate, i.e., habitats delineated per planned hectare, did not differ significantly between the four actors $(P=0.219)$. Although not statistically significant, the noticeable differences in mean delineation rates between public and private sector planners suggest the possibility that many of the actors responsible for on-site commercial operations delineated habitats at a higher rate compared with the RFC planners responsible for large-scale, long-term planning.

There were significant but rather modest differences in competencies across the four organization types (Table 3). The RFCs invested heavily in spatial tools, particularly when compared with industry and entrepreneurs (Bonferroni adjusted $P=0.000$ ). The RFC planners were relatively less experienced, i.e., younger, in comparison with industry foresters $(P$ $=0.000)$ and less educated. Compared with foresters working in other organizations, RFC planners were also significantly less dependent on information from actors directly engaged in forestry operations $(P=0.000)$ and were more tightly connected with forestry administration.

In contrast, forest planners working in large-scale commercial firms were more experienced and older. Their organizations had invested relatively heavily in procedures and particularly in third-party ecocertification compared to all other organization types $(P=0.000)$. Industry and local forest management associations (LFMAs) relied more heavily on information from actors directly involved in forestry operations than did RFCs $(P=$ 0.000). LFMAs applied systems of internal coordination and reported better access to spatial tools than did industry $(P=0.000)$. Entrepreneurs were a diverse group of highly educated actors working in close contact with actors engaged in 
Table 3. Analysis of variance between actor behavior and resource mobilization: mean and statistical significance of difference between groups. Values in bold are the highest means of those variables whose analysis of variance was significant at $P<0.005$. RFC stands for regional forestry center $(N=44)$; LFMA, for local forest management association $(N=111)$; I, for industry $(N=132)$; and $\mathrm{E}$, for entrepreneur $(N=13)$.

\begin{tabular}{|c|c|c|c|c|c|}
\hline & \multicolumn{4}{|c|}{ Mean } & \multirow{2}{*}{$\frac{\text { MANOVA }}{P}$} \\
\hline & RFC & FMA & $\mathrm{I}$ & $\mathrm{E}$ & \\
\hline \multicolumn{6}{|l|}{ Behavior } \\
\hline Planning (ha) & 1816.48 & 409.03 & 287.95 & 235.70 & 0.000 \\
\hline Habitat delineation (number) & 55.55 & 13.72 & 8.94 & 5.77 & 0.000 \\
\hline Habitat delineation rate & 0.03 & 0.06 & 0.06 & 0.05 & 0.219 \\
\hline \multicolumn{6}{|l|}{ Human capital } \\
\hline Education (scale 0-4) & 1.91 & 2.07 & 2.18 & 2.38 & 0.048 \\
\hline Biodiversity training (scale $0-4$ ) & 2.76 & 2.76 & 2.92 & 2.08 & 0.010 \\
\hline Experience (years of service) & 16.85 & 19.51 & 23.21 & 14.92 & 0.000 \\
\hline \multicolumn{6}{|l|}{ Organizational resources } \\
\hline Procedures & 0.08 & -0.33 & 0.31 & -0.74 & 0.000 \\
\hline External coordination & -0.30 & 0.11 & -0.02 & 0.57 & 0.013 \\
\hline Internal coordination & -0.39 & 0.15 & 0.08 & -0.52 & 0.001 \\
\hline Support & 0.00 & 0.03 & 0.02 & -0.46 & 0.413 \\
\hline Spatial tools & 0.59 & 0.18 & -0.34 & -0.61 & 0.000 \\
\hline Time and money & 0.01 & -0.05 & 0.05 & -0.11 & 0.868 \\
\hline Certified management systems (scale $0-4$ ) & 1.31 & 1.12 & 1.99 & 0.77 & 0.000 \\
\hline \multicolumn{6}{|l|}{ Information sourcing } \\
\hline Public agencies & 0.05 & -0.04 & 0.01 & 0.02 & 0.948 \\
\hline Forestry operations & -0.95 & 0.22 & 0.19 & 0.18 & 0.000 \\
\hline Internal & $\mathbf{0 . 4 3}$ & -0.06 & -0.14 & 0.05 & 0.004 \\
\hline Forest administration & 0.73 & -0.06 & -0.23 & -0.21 & 0.000 \\
\hline
\end{tabular}


forestry operations. In summary, we observed statistically significant differences in resources, most of which stemmed from differences between the public and private sectors.

\section{Contribution of various resources to habitat conservation}

To evaluate the extent to which variance in resources explained variance in habitat conservation, we regressed our measures of resources and organization types, with RFCs as the base case, onto $\log _{10}$-transformed variables of habitat delineation and delineation rate. To evaluate our models and assess alternatives, we ran stepwise regression analyses. The stepwise procedure yielded the same significant effects but offered no additional explanatory power. Additionally, we analyzed the interactions between relevant sets of resources as well as potential interactions between resources and organization types. We found no significant interaction effects.

The models explained about a third of the variance in delineation and about $10 \%$ of the variance in delineation rate (Table 4). These results were largely attributable to organization type. All three types had a strong, highly significant negative effect on habitat delineation, reinforcing the status of RFCs as the lead actor in incorporating habitat conservation into forest management planning. With regard to habitat delineation rate, foresters working in industry identified habitats more frequently than did basecase RFC foresters with similar resource endowments $(P=0.020)$.

Controlling for organization type, resources had a very small effect on habitat conservation (Table 4). In explaining variance in the two measures of habitat conservation, information sourcing from forestry operations stood out. Communication with actors directly engaged in field-level operations influenced habitat delineation rate $(P=0.038)$ and, in particular, habitat delineation $(P=0.001)$. Biodiversity training also affected habitat delineation rate $(P=0.014)$ and had a weak, marginally nonsignificant influence on habitat delineation $(P=0.060)$. The partial regression coefficients associated with these three $P$ values were the highest of all the coefficients attached to resources in Table 4. In general, resources had a positive sign, suggesting some support for the general claim that resources support performance.
Because organization type explained a large share of delineation, we further explored differences in mobilization of resources by analyzing the effects of resources on conservation behaviors separately for RFCs, LFMAs, and industry (Table 5). We excluded entrepreneurs because of the small sample size. In general, the explanatory power of the models was weak. The ability of RFCs to conserve habitats appeared to be supported by investments in education and information sourcing from actors engaged directly in forestry operations. In the case of LFMAs, information sourcing from forestry operations actors and internal coordination capabilities contributed to habitat delineation. For industry, training and support advanced conservation. Information sourcing from public agencies and investments in spatial tools had a negative impact on delineation rate in industry.

Resources did not substantially explain delineation at the level of individual organization types, with the notable exception of our model of industry's delineation rate, in which biodiversity training had strong explanatory power (Table 5). Interestingly, organizations that had significantly higher stocks of a given resource relative to other organizations (Table 3) did not significantly rely on those particular resources in habitat delineation (Table 5), which indicates that the resources were used evenly by their planning staff. RFC staff did not differentiate in their use of spatial tools to explain habitat delineation, although the RFCs had relatively high capacity in this resource. On the other hand, although their investments in forestry operations contacts and education were low compared with those of other organizations, their planners used these resources successfully in habitat delineation. Industry's high level of information sourcing did not explain variations in habitat delineation.

\section{DISCUSSION}

Commitment to the integration of biodiversity conservation into timber production, which is a departure from strict reliance on the segregation of parkland from land exploited for commercial purposes, requires actors from the public and private sectors as well as civil society to confront the challenges of adaptation and learning. Based on the assumptions that increased social demand for biodiversity conservation requires investment in new competencies and constitutes an axis around 
Table 4. Regression analyses of organization types and competencies on delineation and delineation rate (both $\log _{10}$ transformed): standardized beta and significance. Bold values are significant at $P>0.1$.

\begin{tabular}{|c|c|c|c|c|c|}
\hline & & \multicolumn{2}{|c|}{$\begin{array}{l}\text { Habitat delineation } \\
\qquad(N=287)\end{array}$} & \multicolumn{2}{|c|}{$\begin{array}{l}\text { Delineation rate } \\
\qquad(N=284)\end{array}$} \\
\hline & & Beta & $P$ & Beta & $P$ \\
\hline \multicolumn{6}{|c|}{ Organization type } \\
\hline & Local forest management association & -0.691 & 0.000 & 0.125 & 0.202 \\
\hline & Industry & -0.866 & 0.000 & 0.243 & 0.020 \\
\hline & Entrepreneurs & -0.406 & 0.000 & 0.089 & 0.199 \\
\hline \multicolumn{6}{|c|}{ Human capital } \\
\hline & Education & 0.050 & 0.330 & 0.039 & 0.511 \\
\hline & Biodiversity training & 0.096 & 0.060 & 0.147 & 0.014 \\
\hline & Experience & 0.022 & 0.680 & -0.092 & 0.139 \\
\hline \multicolumn{6}{|c|}{ Organizational resources } \\
\hline & Procedures & 0.048 & 0.364 & 0.028 & 0.649 \\
\hline & External coordination & 0.088 & 0.080 & 0.070 & 0.232 \\
\hline & Internal coordination & 0.058 & 0.256 & 0.007 & 0.904 \\
\hline & Support & -0.020 & 0.694 & 0.087 & 0.147 \\
\hline & Spatial tools & 0.060 & 0.268 & -0.048 & 0.437 \\
\hline & Time and money & 0.003 & 0.947 & -0.002 & 0.971 \\
\hline & Certified management system & 0.064 & 0.251 & 0.078 & 0.229 \\
\hline \multicolumn{6}{|c|}{ Information sourcing } \\
\hline & Public agencies & -0.033 & 0.504 & -0.045 & 0.435 \\
\hline & Forestry operations & 0.192 & 0.001 & 0.137 & 0.038 \\
\hline & Internal & -0.036 & 0.488 & 0.073 & 0.227 \\
\hline & Forest administration & 0.021 & 0.695 & -0.045 & 0.474 \\
\hline $\mathrm{R}^{2}$ & & \multicolumn{2}{|c|}{0.368} & \multicolumn{2}{|c|}{0.161} \\
\hline \multicolumn{2}{|l|}{ Adjusted R² } & \multicolumn{2}{|c|}{0.328} & \multicolumn{2}{|c|}{0.108} \\
\hline \multicolumn{2}{|l|}{ SE } & \multicolumn{2}{|c|}{0.391} & \multicolumn{2}{|c|}{0.442} \\
\hline
\end{tabular}


Table 5. Regression analyses of competencies on respondents' delineation and delineation rate $\left(\log _{10}\right.$ transformed) in three organization types: standardized beta and significance in parenthesis. Bold values are significant at $P>0.1$. HD stands for habitat delineation and HDR for habitat delineation rate.

\begin{tabular}{|c|c|c|c|c|c|c|}
\hline & \multicolumn{2}{|c|}{$\begin{array}{l}\text { Regional } \\
\text { forestry center } \\
\quad(N=52)\end{array}$} & \multicolumn{2}{|c|}{$\begin{array}{c}\text { Local forest } \\
\text { management association } \\
(N=105)\end{array}$} & \multicolumn{2}{|c|}{$\begin{array}{c}\text { Industry } \\
(N=119)\end{array}$} \\
\hline & HD & HDR & HD & HDR & HD & HDR \\
\hline \multicolumn{7}{|l|}{ Human capital } \\
\hline Education & $\begin{array}{c}0.282 \\
(0.080)\end{array}$ & $\begin{array}{c}\mathbf{0 . 2 9 1} \\
(\mathbf{0 . 0 5 5})\end{array}$ & $\begin{array}{c}0.104 \\
(0.297)\end{array}$ & $\begin{array}{c}0.106 \\
(0.291)\end{array}$ & $\begin{array}{c}0.013 \\
(0.896)\end{array}$ & $\begin{array}{l}-0.085 \\
(0.366)\end{array}$ \\
\hline Biodiversity training & $\begin{array}{c}0.024 \\
(0.882)\end{array}$ & $\begin{array}{c}0.160 \\
(0.292)\end{array}$ & $\begin{array}{c}0.090 \\
(0.390)\end{array}$ & $\begin{array}{c}0.032 \\
(0.762)\end{array}$ & $\begin{array}{c}0.194 \\
(0.050)\end{array}$ & $\begin{array}{c}0.303 \\
(\mathbf{0 . 0 0 2})\end{array}$ \\
\hline Experience & $\begin{array}{c}0.094 \\
(0.572)\end{array}$ & $\begin{array}{c}0.005 \\
(0.976)\end{array}$ & $\begin{array}{l}-0.073 \\
(0.495)\end{array}$ & $\begin{array}{l}-0.168 \\
(0.119)\end{array}$ & $\begin{array}{c}0.039 \\
(0.696)\end{array}$ & $\begin{array}{l}-0.074 \\
(0.437)\end{array}$ \\
\hline \multicolumn{7}{|l|}{ Organizational resources } \\
\hline Procedures & $\begin{array}{c}0.034 \\
(0.848)\end{array}$ & $\begin{array}{c}0.152 \\
(0.366)\end{array}$ & $\begin{array}{c}0.150 \\
(0.167)\end{array}$ & $\begin{array}{c}0.021 \\
(0.847)\end{array}$ & $\begin{array}{l}-0.124 \\
(0.198)\end{array}$ & $\begin{array}{l}-0.042 \\
(0.648)\end{array}$ \\
\hline External coordination & $\begin{array}{c}0.034 \\
(0.824)\end{array}$ & $\begin{array}{c}0.119 \\
(0.408)\end{array}$ & $\begin{array}{c}0.100 \\
(0.312)\end{array}$ & $\begin{array}{c}0.052 \\
(0.598)\end{array}$ & $\begin{array}{c}0.152 \\
(0.119)\end{array}$ & $\begin{array}{c}0.085 \\
(0.361)\end{array}$ \\
\hline Internal coordination & $\begin{array}{c}0.055 \\
(0.738)\end{array}$ & $\begin{array}{c}0.102 \\
(0.505)\end{array}$ & $\begin{array}{c}0.124 \\
(0.217)\end{array}$ & $\begin{array}{c}\mathbf{0 . 1 9 8} \\
(\mathbf{0 . 0 5 4})\end{array}$ & $\begin{array}{c}0.093 \\
(0.323)\end{array}$ & $\begin{array}{l}-0.111 \\
(0.220)\end{array}$ \\
\hline Support & $\begin{array}{c}0.047 \\
(0.785)\end{array}$ & $\begin{array}{c}0.101 \\
(0.534)\end{array}$ & $\begin{array}{l}-0.040 \\
(0.713)\end{array}$ & $\begin{array}{l}-0.005 \\
(0.961)\end{array}$ & $\begin{array}{l}-0.032 \\
(0.742)\end{array}$ & $\begin{array}{c}0.202 \\
(\mathbf{0 . 0 3 0})\end{array}$ \\
\hline Spatial tools & $\begin{array}{l}0.140 \\
(0.403)\end{array}$ & $\begin{array}{c}0.048 \\
(0.761)\end{array}$ & $\begin{array}{c}0.025 \\
(0.819)\end{array}$ & $\begin{array}{c}0.061 \\
(0.574)\end{array}$ & $\begin{array}{c}0.014 \\
(0.882)\end{array}$ & $\begin{array}{l}-\mathbf{- 0 . 1 8 8} \\
(\mathbf{0 . 0 4 3 )}\end{array}$ \\
\hline Time and money & $\begin{array}{c}0.212 \\
(0.181)\end{array}$ & $\begin{array}{c}0.220 \\
(0.140)\end{array}$ & $\begin{array}{c}0.085 \\
(0.418)\end{array}$ & $\begin{array}{c}0.012 \\
(0.907)\end{array}$ & $\begin{array}{l}-0.162 \\
(0.105)\end{array}$ & $\begin{array}{l}-0.063 \\
(0.512)\end{array}$ \\
\hline Certified management system & $\begin{array}{l}-0.034 \\
(0.846)\end{array}$ & $\begin{array}{c}0.074 \\
(0.654)\end{array}$ & $\begin{array}{c}0.085 \\
(0.432)\end{array}$ & $\begin{array}{c}0.134 \\
(0.215)\end{array}$ & $\begin{array}{c}0.062 \\
(0.539)\end{array}$ & $\begin{array}{l}-0.045 \\
(0.637)\end{array}$ \\
\hline \multicolumn{7}{|l|}{ Information sourcing } \\
\hline Public agencies & $\begin{array}{l}-0.154 \\
(0.313)\end{array}$ & $\begin{array}{l}-0.107 \\
(0.454)\end{array}$ & $\begin{array}{c}0.010 \\
(0.921)\end{array}$ & $\begin{array}{c}0.139 \\
(0.183)\end{array}$ & $\begin{array}{l}-0.135 \\
(0.155)\end{array}$ & $\begin{array}{l}-0.255 \\
(0.006)\end{array}$ \\
\hline Forestry operations & $\begin{array}{c}0.399 \\
(0.057)\end{array}$ & $\begin{array}{c}\mathbf{0 . 4 3 6} \\
(\mathbf{0 . 0 2 8})\end{array}$ & $\begin{array}{c}0.285 \\
(0.007)\end{array}$ & $\begin{array}{c}0.137 \\
(0.186)\end{array}$ & $\begin{array}{c}0.148 \\
(0.139)\end{array}$ & $\begin{array}{c}0.083 \\
(0.397)\end{array}$ \\
\hline Internal & $\begin{array}{c}0.235 \\
(0.151)\end{array}$ & $\begin{array}{c}0.133 \\
(0.382)\end{array}$ & $\begin{array}{l}-0.160 \\
(0.126)\end{array}$ & $\begin{array}{c}0.086 \\
(0.406)\end{array}$ & $\begin{array}{l}-0.134 \\
(0.185)\end{array}$ & $\begin{array}{c}0.064 \\
(0.508)\end{array}$ \\
\hline Forest administration & $\begin{array}{l}-0.175 \\
(0.396)\end{array}$ & $\begin{array}{l}-0.216 \\
(0.264)\end{array}$ & $\begin{array}{c}0.090 \\
(0.398)\end{array}$ & $\begin{array}{l}-0.004 \\
(0.973)\end{array}$ & $\begin{array}{l}-0.025 \\
(0.794)\end{array}$ & $\begin{array}{l}-0.049 \\
(0.599)\end{array}$ \\
\hline
\end{tabular}




\begin{tabular}{lllllll}
$\mathrm{R}^{2}$ & 0.255 & 0.345 & 0.184 & 0.187 & 0.156 & 0.237 \\
Adjusted $\mathrm{R}^{2}$ & -0.026 & 0.098 & 0.057 & 0.060 & 0.043 & 0.132 \\
$\mathrm{SE}$ & 0.466 & 0.420 & 0.406 & 0.458 & 0.349 & 0.411 \\
\hline
\end{tabular}

which actors compete for market share and legitimacy, we have studied resource mobilization among forestry actors who are responsible for conserving ecologically significant habitats in nonindustrial private forests. We believe that resource flows underlie competency formation, which in turn underlies the capacity to fulfill commitments to sustainability (Wolf and Primmer 2006).

Our results provide a profile of the human capital, organizational resources, and information networks in place to support habitat delineation on private forest land in Finland. The analysis of the resources available to the organizations that manage natural resources provides a basis for evaluating the scale, scope, and distribution of investment in implementation of an integrated conservation strategy. These data inform our understanding of patterns of investment at the level of various types of organizations and the sector as a whole, and allow us to identify the division of labor in habitat conservation among the various public and private sector actors. The results are a baseline against which we can chart future investments in integrated biodiversity conservation and forest management. Additionally, they support critical reflection on the concepts and methods available for analyzing adaptation for sustainable development within an organizational context.

\section{Functional roles in delineation}

We find that actors in the public and private sectors have distinct roles in habitat delineation. The specialized planners in public sector RFCs are responsible for large-scale forestry planning and, in this role, delineate a great share of habitats. Private sector foresters work at a finer scale and often build upon the findings of the efforts of planners in the public sector. The habitat delineation rate does not differ significantly among the organizations. The positive interpretation of uniform behavior across classes of actors, despite their different roles, is that they are equally well positioned to identify and conserve habitats. In this sense, public policies could reasonably target all relevant audiences. More pessimistically, recalling Pykälä's (2007) claims regarding a general failure to implement regulatory controls on habitats, we might conclude that the actors share a bounded commitment to delineation and maintain a conservative delineation rate determined conventionally and based on a professional norm (Ascher 2001, Pregernig 2001). Ethnographic approaches and case study research are needed to advance our understanding of the factors that shape delineation rates and delineation failures.

Our analysis shows that, resource endowments being equal, those foresters involved in timber trade and harvesting delineate habitats more frequently than other foresters. This result highlights the fact that final decisions regarding conservation and degradation of habitats are made on site by commercial actors as part of operational planning and execution. Industry's performance can also be an indication of companies' concern about their reputation in the marketplace and in society. In this sense, delineating habitats more frequently may be an adaptive response to legitimacy pressure and part of a greening strategy (Russo and Fouts 1997, Kagan et al. 2003, Wolf and Primmer 2006).

\section{Mobilization of competencies}

The resource-based view of organizations and socioeconomic change is heavily focused on idiosyncrasies as engines of innovation and adaptation (Barney 1991, Sharma and Vredenbug 1998), but we find no indications of idiosyncrasy in our case. In general, our findings indicate a high degree of homogeneity in resource stocks and flows among organizations in the sector. By and large, organizations have not invested in resources that support habitat delineation in ways that significantly 
differentiate them from others in the population. Furthermore, individuals who delineate substantial numbers of habitats do not have significantly different resources at their disposal relative to foresters who do not delineate many habitats. The lack of differentiation and the rather weak indications of investment across the entire population can be interpreted as part of a general tendency of actors to avoid risky "green" investments that might not pay off by lowering costs or increasing competitiveness and legitimacy (Rugman and Verbeke 1998).

The disciplinary orientation and level of education of the workforce are particularly uniform, as is typical of the forest sector (Koontz and Bondine 2008). We find minimal evidence that public, private, and collective organizations have different competencies or make different investments. In looking for differences, we note that RFCs invest more heavily in databases and maps in relative terms, whereas their planners are generally poorly connected to those who make operational decisions in commercial activities such as harvesting. These local information resources are, however, a productive resource in their habitat delineation, illustrating a degree of heterogeneity among planners working in RFCs. Similarly, although planners in these public sector organizations are younger and less highly educated relative to other organizations, education contributes to habitat conservation within RFCs. This can perhaps be attributed to increased attention to biodiversity conservation in the curricula of more recent forestry graduates.

Private sector and collective organizations rely on resources that support direct engagement in habitat conservation in particular locations and in conjunction with local people. Contact with actors engaged directly in operations in the forest apparently supports informal information flows and ability to obtain last-minute confirmation before actual operations. Forest management associations, by definition locally situated interfaces between landowners and industry, rely heavily on contacts with operational actors in habitat conservation. As we observed for industry, contact with public agencies and investments in GPS and GIS, both of which may support management from a desk at a distance and take away from time spent working in the forest and talking with local actors on site, contribute negatively to the habitat delineation rate. As discussed below in more detail, local engagement of forestry professionals would seem to be important for habitat conservation.

Industry relies significantly on biodiversity training, which can be acquired in a tailored fashion to complement formal education. Industry has invested in coordination mechanisms in ways typical of organizations in competitive environments (Nelson and Winter 1982, March 1999), e.g., support systems and external certification. These investments could be an indication that commercial firms are confronting greater pressures to adapt than are other actors and that corporate greening is emerging as an axis of competition (Russo and Fouts 1997). Having said this, we have not identified substantially greater or more productive investments by large firms relative to other actors in our study.

\section{Crucial information sourcing from operational actors}

In seeking to identify the particular resources that support habitat delineation within an organizational context, we found that access to information from actors directly engaged in forestry operations, i.e., local actors with a hand in the value chain, is a particularly important asset. This finding clearly emphasizes the importance of communication and interaction, and points to the significance of contact with people directly involved in selling, cutting, and buying timber in the specific locations in which habitats are found. Rametsteiner and Weiss (2006) have found innovation in commercial firms in forestry to be supported by vertical linkages in commodity chains, such as personal communication downstream with customers and upstream with suppliers. Just as we found, communication with and between agencies, regulators, and scientists is not sufficient. Local actors must be involved (Lebel et al. 2006, cf. Eriksson and Hammer 2006, Roux et al. 2006).

Information sourcing by industry from public agencies had a negative effect on habitat delineation. Although formal registries are generally considered important references for foresters working in the field (Eriksson and Hammer 2006), this empirical result potentially indicates that contacts with the regulatory agencies that control habitat registries, i.e., spatially referenced habitat inventories, may be focused on confirming the location and legal status of habitats rather than getting information to support the 
identification of new habitats. If commercial forestry planners are simply "checking in" with public officials to argue or receive acknowledgment that a habitat is not worthy of conservation, contact with those regulators might constrain delineation. Again, qualitative research is needed to better understand the role of regulatory agencies in conservation practice.

\section{Limitations of our approach and analysis}

Based on a need to understand the adaptive behavior of organizations confronting new demands for environmental quality, we have pursued a systematic accounting of resources that support habitat conservation and investigated the effects of those resources on habitat delineation. Resources do not, however, explain a notable share of delineation behavior. By and large, the empirical results do not provide strong support for our conceptual arguments regarding expectations for investments in resources, the differentiation of organizations on the basis of resources, and the productivity of resources in conservation. This kind of low explanatory power is not uncommon in empirical applications of resource-based theory applied to organizations. Greening of organizations and sectors is typically not well understood (Sharma and Vredenburg 1998, Christmann 2000), and what constitutes a productive resource in a particular organizational setting continues to elude management scholars and managers (Foss 1997).

It is also possible that local contextual ecological and institutional factors (Ascher 2001, Campbell et al. 2001) not included in our study are far more powerful than organizational resources as explanatory factors in habitat delineation. We have assumed that forest planners have relatively equal opportunities to encounter and delineate habitats, although the density of habitats may vary geographically at scales that invalidate this assumption. Even when assuming homogeneous spatial distribution of habitats, Kotiaho and Selonen (2006) found differences in the size of the habitats inventoried across the landscape and hypothesized that these differences derived from local ecological variation. In terms of institutional variation, responsibility for habitat delineation is a uniform requirement for actors in the forest nationwide, but differences in local knowledge, norms, and enforcement capabilities could be important determinants of outcomes, including delineation, at the level of communities.
A possible methodological explanation for the low explanatory power of resources could be the nature of the resources we measure. We have tried to make an accounting of resources that lend themselves to objective measurement (Galbreath 2005). For example, the level of education is easy to measure, but it is very uniform within the population we study. Because variance is quite low, it is not easy to make sense of any pattern in terms of its effect on the behaviors of interest. Variables such as leadership and organizational culture and norms, all attributes that are not easily defined and measured, yet are likely important in some contexts, fall outside our investigation (Robbins et al. 2008). We assume that some organizations have an atmosphere in which experimentation, risk taking, and even failure are rewarded, and we assume that such an atmosphere can facilitate innovation and adaptation. Integration of professional norms and organizational culture, as well as individual judgments, into the analysis is an important future challenge. Structural socioeconomic and social-ecological variables, e. g., regional economic dependence on logging, local access to parks and protected areas, could shed additional light on the pressures for and the process of adaptation.

\section{CONCLUSION}

We have developed an approach to analyzing the responses of natural resource management organizations to evolving social demand for biodiversity conservation in an effort to advance our understanding of adaptation to environmental change. This empirical examination of the scale, scope, and distribution of investments by organizations and the sector as a whole highlights modes of adaptation by public, private, and collective actors in a particular natural resource setting and institutional context in which legal obligations, technical norms, and standards of accountability are evolving. In seeking to integrate considerations of human capital, managerial strategies, and networking behaviors, the empirical scheme developed here complements environmental management studies focused strictly on the accounting of external information sources and the literature on deliberative policy and practice.

Adaptation involves exploring new practices and bringing new resources to bear in addition to exploiting existing modes of functioning and investing in fine-tuning the allocation of existing 
resources. Because innovation and adaptation are, in part, contingent on a diversity of approaches, and we tend to learn by experience which investments and strategies are functionally advantageous, the challenge of environmental change is particularly demanding in an institutional setting characterized by low diversity and processes of isomorphism, as is the case in Finnish forestry. Central coordination of training and silvicultural practice and a tendency to rely on collective interpretations of the social and political landscape serve to reinforce strong professional norms and traditional modes of sectoral development. The positive policy message that stems from this collectively oriented institutional structure is that few actors in the sector get left behind and commitments can be efficiently implemented. The challenges lie in potentially slow progress and constrained opportunities for radical, transformative innovation.

Sudden environmental changes and shifts in social perceptions of ecological risks might trigger differentiating behavior among forestry actors and initiate innovation. To date, however, the biodiversity conservation challenge, so powerfully represented in policy and markets, has not disrupted the traditional structures and modes of adaptation in Finnish forestry. In addition to fostering cooperation and collective structures that support sensing and adapting to a changing environment, natural resource governance should be designed to stimulate diversification through learning and innovation founded on localized initiatives, knowledge, and networks.

Responses to this article can be read online at: http://www.ecologyandsociety.org/voll4/iss2/art27/ responses/

\section{Acknowledgments:}

We wish to thank Mikael Hildén, Heimo Karppinen, Jari Kuuluvainen, Aija Leiponen, Per Mickwitz, Heli Saarikoski, and Patrick Sullivan as well as two anonymous reviewers for ideas and useful comments on earlier drafts of this paper. Our research has been financially supported by the Maj and Tor Nessling Foundation and the Academy of Finland (project no. 206020).

\section{LITERATURE CITED}

Armitage, D., M. Marschke, and R. Plummer. 2008. Adaptive co-management and the paradox of learning. Global Environmental Change 18:86-98.

Armstrong, J. S., and T. S. Overton. 1977. Estimating non-response bias in mail surveys. Journal of Marketing Research 14:396-402.

Ascher W. 2001. Coping with complexity and organizational interests in natural resource management. Ecosystems 4:742-757.

Auvinen, A.-P., M. Hildén, H. Toivonen, E. Primmer, J. Niemelä, K. Aapala, S. Bäck, P. Härmä, J. Ikävalko, E. Järvenpää, H. Kaipiainen, K. T. Korhonen, H. Kumela, L. Kärkkäinen, J. Lankoski, M. Laukkanen, I. Mannerkoski, T. Nuutinen, A. Nöjd, P. Punttila, O. Salminen, G. Söderman, M. Törmä, and R. Virkkala. 2007. Evaluation of the Finnish National Biodiversity Action Plan 1997-2005. Monographs of the Boreal Environmental Research, Number 29. Finnish Environment Institute, Helsinki, Finland. Available online at: http://www.ymparisto.fi/download. asp? contentid $=75895 \&$ lan $=$ en .

Barney, J. 1991. Firm resources and sustained competitive advantage. Advances in Strategic Management 17:203-227.

Brechin, S., P. Wilshusen, C. Fortwangler, and P. West. 2003. Contested nature: promoting international biodiversity with social justice in the twenty-first century. State University of New York Press, Albany, New York, USA.

Campbell, B., J. A. Sayer, P. Frost, S. Vermeulen, M. Ruiz Pérez, A. Cunningham, and R. Prabhu. 2001. Assessing the performance of natural resource systems. Conservation Ecology 5(2): 22. [online] URL: http://www.consecol.org/vol5/iss2/art22/

Chandler, A. D. 1997. Strategy and structure. Pages 40-51 in N. J. Foss, editor. Resources, firms, and strategies: a reader in the resource-based perspective. Oxford University Press, New York, New York, USA.

Christmann, P. 2000. Effects of "best practices" of environmental management on cost advantage: the role of complementary assets. Academy of Management Journal 43(4):663-680. 
Cyert, R. M., and J. G. March. 1992. A behavioral theory of the firm. Second edition. Blackwell, Malden, Massachusetts, USA.

DiMaggio, P. J., and W. Powell. 1983. "The iron cage revisited": institutional isomorphism and collective rationality in organizational fields. American Sociological Review 48:147-60.

Eriksson S., and M. Hammer. 2006. The challenge of combining timber production and biodiversity conservation for long-term ecosystem functioning - a case study of Swedish boreal forestry. Forest Ecology and Management 237:208-217.

Farrell E. P., E. Führer, D. Ryan, F. Andersson, R. Hpttl, and P. Piussi. 2000. European forest ecosystems: building the future on the legacy of the past. Forest Ecology and Management 132:5-20.

Finnish Forest Research Institute. 2007. Finnish statistical yearbook of forestry. Finnish Forest Research Institute, Vantaa, Finland.

Finnish Forestry Certification Council (FFCS). 2003. Standard criteria for group certification for the area of a forestry centre. FFCS, Helsinki, Finland.

Folke, C., T. Hahn , P. Olsson, and J. Norberg. 2005. Adaptive governance of social-ecological systems. Annual Review of Environmental Resources 30:441-473.

Foss, N. J., editor. 1997. Resources, firms, and strategies; a reader in the resource-based perspective. Oxford University Press, New York, New York, USA.

Galbreath, J. 2005. Which resources matter the most to firm success? An exploratory study of resource-based theory. Technovation 25:979-987.

Graham, R. T., and T. B. Jain. 1998. Silviculture's role in managing boreal forests. Conservation Ecology 2(2): 8. [online] URL: http://www.consecol. org/vol2/iss2/art8/.

Hart, S. 1995. A natural-resource-based view of the firm. Academy of Management Review 20 (4):986-1014.
Hartley, M. J. 2002. Rationale and methods for conserving biodiversity in plantation forests. Forest Ecology and Management 155:81-95.

Holling, C. S. 2001. Understanding the complexity of economic, ecological, and social systems. Ecosystems 4:390-405.

Hujala, T., J. Pykäläinen, and J. Tikkanen. 2007. Decision making among Finnish non-industrial private forest owners: the role of professional opinion and desire to learn. Scandinavian Journal of Forest Research 22(5):454-463.

Judge, W. Q., and D. Elenkov. 2005. Organizational capacity for change and environmental performance: an empirical assessment of Bulgarian firms. Journal of Business Research 58:893-901.

Just, D., S. Wolf, and D. Zilberman. 2006. Effect of information formats on information services: analysis of four selected agricultural commodities. Agricultural Economics 35:289-301.

Kagan, R. A., D. Thornton, and N. Gunningham. 2003. Explaining corporate environmental performance: How does regulation matter? Law \& Society Review 37(1):51-90.

Koontz, T. M., and J. Bondine. 2008. Implementing ecosystem management in public agencies: lessons from the U.S. Bureau of Land Management and the Forest Service. Conservation Biology 22(1):60-69.

Kotiaho, J., and V. Selonen. 2006. Metsäain erityisen tärkeiden elinympäristöjen kartoituksen laadun ja luotettavuuden analyysi. Suomen ympäristö 29(2006). Suomen ympäristökeskus, Helsinki, Finland.

Lado, A. A., and M. C. Wilson. 1994. Human resource systems and sustained competitive advantage; a competency-based perspective. Academy of Management Review 19(4):699-727.

Lebel, L., J. M. Anderies, B. Campbell, C. Folke, S. Hatfield-Dodds, T. P. Hughes. and J. Wilson. 2006. Governance and the capacity to manage resilience in regional social-ecological systems. Ecology and Society 11(1): 19. [online] URL: http: //www.ecologyandsociety.org/vol11/iss1/art19/. 
Lindenmayer, D. B., and J. F. Franklin. 2002. Conserving forest biodiversity: a comprehensive multiscaled approach. Island Press, Washington, D. C., USA.

March, J. G. 1999. Exploration and exploitation in organizational learning. Organization Science 2 (Special Issue: Organizational Learning: Papers in Honor of (and by) James G. March):71-87.

McCarthy, J. 2005. Multifunctional rural geographies: reactionary or radical? Progress in Human Geography 29(6):1-10.

Menguc, B., and L. K. Ozanne. 2005. Challenges of the "green imperative": a natural resource-based approach to the environmental orientation-business performance relationship. Journal of Business Research 58:430-438.

Millennium Ecosystem Assessment. 2005. Ecosystems and human well-being: synthesis. Island Press, Washington, D.C., USA.

Nelson R. R. 1991. Why do firms differ, and how does it matter? Strategic Management Journal 12 (Special Issue: Fundamental Research Issues in Strategy and Economics):61-74.

Nelson R. R., and S. G. Winter. 1982. $A n$ evolutionary theory of economic change. Belknap Press of Harvard University Press, Cambridge, Massachusetts, USA.

Norgaard, R. B. 1994. Development betrayed: the end of progress and a coevolutionary revisioning of the future. Routledge, London, UK.

Ollonqvist, P. 1998. Metsäpolitiikka ja sen tekijät -Pitkä linja 1928-1997. Metsälehti Kustannus, Helsinki, Finland.

Pimm, S. L., G. J. Russell, J. L. Gittleman, and T.M. Brooks. 1995. The future of biodiversity. Science 269:347-350.

Porter, M. E., and C. van der Linde. 1995. Toward a new conception of the environmentcompetitiveness relationship. Journal of Economic Perspectives 9(4):97-118.

Pregernig, M. 2001. Values of forestry professionals and their implications for the applicability of policy instruments. Scandinavian Journal of Forest Research 16(3):278-288.
Pykälä, J. 2004. Effects of new forestry practices on rare epiphytic macrolichens. Conservation Biology 18(3):831-838.

Pykälä, J. 2007. Implementation of forest act habitats in Finland: Does it protect the right habitats for threatened species? Forest Ecology and Management 242:281-287.

Rametsteiner, E., and G. Weiss. 2006. Innovation and innovation policy in forestry: linking innovation process with systems models. Forest Policy and Economics 8:691-703.

Ritter, T., and H. G. Gemünden. 2003. Network competence: its impact on innovation success and its antecedents. Journal of Business Research 56:745-755.

Robbins, P., R. Farnsworth, and J. P. Jones III. 2008. Insects and institutions: How do bureaucracies adapt to emerging environmental problems. Journal of Environmental Policy and Planning 10(1):95-112.

Rosenberg, N. 1982. Learning by using. Pages 120-140 in N. Rosenberg, editor. Inside the black box: technology and economics. Cambridge University Press, Cambridge, UK.

Roux, D. J., K. H. Rogers, H. C. Biggs, P. J. Ashton, and A. Sergeant. 2006. Bridging the science-management divide: moving from unidirectional knowledge transfer to knowledge interfacing and sharing. Ecology and Society 11(1): 4. [online] URL: http://www.ecologyandsociety.org/vol11/iss 1/ art4/.

Rugman, A. M., and A. Verbeke. 1998. Corporate strategies and environmental regulations: an organizing framework. Strategic Management Journal 19(4):363-375.

Russo, M. V., and P. A., Fouts. 1997. A resourcebased perspective on corporate environmental performance and profitability. Academy of Management Journal 40(3):534-559.

Sharma, S., and H. Vredenburg. 1998. Proactive corporate environmental strategy and the development of competitively valuable organizational capabilities. Strategic Management Journal 19:729-753. 
Simon, H. A. 1997. Administrative behavior: a study of decision-making processes in administrative organizations. Fourth edition. Free Press, New York, New York, USA.

Sudman, S., N. Bradburn, and N. Schwarz. 1996. Thinking about answers: the application of cognitive processes to survey methodology. JosseyBass, San Francisco, California, USA.

Tabachnick, B. G., and L. S. Fidell. 2001. Using multivariate statistics. Fourth edition. Allyn \& Bacon, Upper Saddle River, New Jersey, USA.

Tàbara, J. D., and C. Pahl-Wostl. 2007. Sustainability learning in natural resource use and management. Ecology and Society 12(2): 3. [online] URL: http://www.ecologyandsociety.org/vol12/iss2/ art3/.

Tapio. 2001. Hyvän metsänhoidon suositukset. Metsätalouden kehittämiskeskus Tapio, Helsinki, Finland.

Wolf, S. A., and J. Klein. 2007. Enter the working forest: discourse analysis in the northern forest. Geoforum 38(5):985-998.

Wolf, S. A., and E. Primmer. 2006. Between incentives and action: a pilot study of biodiversity conservation competencies for multifunctional forest management in Finland. Society and Natural Resources 19:845-861.

Zander, U., and B. Kogut. 1995. Knowledge and the speed of the transfer and imitation of organizational capabilities: an empirical test. Organization Science 6 (Focused Issue: European Perspective on Organization Theory):76-92.

Zollo, M., and S. G. Winter. 2002. Deliberate learning and the evolution of dynamic capabilities. Organization Science 13(3):339-351 


\title{
APPENDIX 1. ORGANIZATIONAL CONTEXT OF HABITAT CONSERVATION IN FINLAND
}

\author{
Habitat delineation as a conservation practice
}

The Finnish Forest Act of 1996 identified habitat conservation as the main biodiversity conservation practice in commercially managed nonindustrial private forests in Finland. In addition to legally defined habitats, forestry actors are mandated to delineate other valuable habitats according to guidelines (Tapio 2001) and eco-certification standards (FFCS 2003).

Conservation of habitats is dependent on their identification and delineation in the forest and on maps and records. In some cases, habitats are recorded on existing databases and maps maintained by public agencies. In other cases, the people planning and executing forestry operations must discover these valuable patches on site. In principle, once the habitats have been identified, evaluated, and delineated, their characteristics are conserved by either restricting or prohibiting forestry operations within the established boundary.

The success of efforts to delineate habitats and conserve biodiversity rests on the performance of four classes of actors and the interactions among them. The performance of these organizations, in turn, is premised on access to and mobilization of competencies. Here we describe the four main actors involved in forest management planning: public agencies, cooperative forest management organizations, largescale commercial firms, and small-scale entrepreneurs.

Public agencies

Regional forestry centers (RFCs) are public agencies that conduct forest inventories and produce longterm plans for nonindustrial private forest owners, including recommendations for forestry operations over 10-yr periods. The 13 RFCs have made a preliminary inventory of all Forest Act habitats, and they control access to these data. However, the dominant position of the RFCs in producing long-term forest management plans is declining. The planning system at the national level is shifting toward hightechnology, low-cost inventories accessible to a range of actors interested in providing customized planning services to private landowners.

\section{Cooperative forest management organizations}

Local forest management associations (LFMAs) provide management services to landowners. In addition to low fees for service, these organizations receive a tax-like fee from almost all forest landowners in Finland, who are, by default, legally defined members. There are currently approximately 140 LFMAs in Finland, each with its own exclusive service territory. Although their service monopoly has eroded over the past $25 \mathrm{yr}$ and large-scale landowners are increasingly contracting for management services provided by industrial timber buyers, LFMAs remain central economic actors. LFMAs are identified by most landowners as their most important information source for questions related to biodiversity conservation. These local organizations have responded to pressure to modernize their service provision and upgrade their competencies by consolidating, and the number of LFMAs has been cut in half over the last $10 \mathrm{yr}$.

\section{Corporations}

Large-scale Finnish forestry corporations are global companies. The top three Finnish companies are among the 10 largest in the world, and Finland produces $7 \%$ of the wood pulp traded in the global market. These companies have sophisticated forest inventory, timber harvesting, and transport systems and increasingly seek to provide one-stop services to landowners. In connection with their procurement functions, they offer services including operation planning all the way through to forest regeneration. As highly visible actors in an extremely competitive globalized sector, these firms are sensitive to social and environmental concerns. 


\section{Entrepreneurs}

In addition to very large firms, there are an increasing number of self-employed foresters and very small firms with fewer than 10 employees. These consulting foresters provide customized management planning and harvesting services and typically do not specialize in environmental or conservation consultancy. 


\section{APPENDIX 2. PRINCIPAL COMPONENT ANALYSES OF ORGANIZATIONAL RESOURCES AND INFORMATION SOURCING}

Table A2-1. Principal component scores for organizational resources (scores $>0.5$ bolded). ${ }^{\dagger}$ [Erratum]

\begin{tabular}{|c|c|c|c|c|c|c|}
\hline \multirow[b]{2}{*}{ Organizational resources } & \multicolumn{6}{|c|}{ Component } \\
\hline & Procedures & $\begin{array}{r}\text { External } \\
\text { coordination }\end{array}$ & $\begin{array}{r}\text { Internal } \\
\text { coordination }\end{array}$ & Support & $\begin{array}{r}\text { Spatial } \\
\text { tools }\end{array}$ & $\begin{array}{r}\text { Time and } \\
\text { money }\end{array}$ \\
\hline Percent variance explained & 15.44 & 12.43 & 12.14 & 9.39 & 9.35 & 8.96 \\
\hline Documentation & 0.836 & 0.224 & 0.061 & 0.049 & 0.133 & 0.003 \\
\hline Monitoring and auditing & 0.734 & 0.343 & 0.155 & 0.088 & -0.071 & 0.018 \\
\hline Information management & 0.694 & 0.186 & 0.179 & 0.131 & 0.291 & 0.044 \\
\hline Guidelines for exceptions/ rare situations & 0.641 & -0.026 & 0.332 & 0.199 & 0.014 & 0.181 \\
\hline Continuous improvement of practices & 0.446 & 0.450 & 0.389 & 0.081 & -0.048 & 0.086 \\
\hline Contact with clients & 0.204 & 0.828 & 0.229 & 0.044 & 0.083 & 0.090 \\
\hline Contact with stakeholders & 0.268 & 0.815 & 0.173 & 0.068 & 0.083 & 0.090 \\
\hline Training & 0.206 & 0.077 & 0.775 & 0.047 & 0.116 & 0.062 \\
\hline $\begin{array}{l}\text { Involvement of workers in developing } \\
\text { organizational practices }\end{array}$ & 0.059 & 0.427 & 0.692 & 0.163 & -0.009 & 0.062 \\
\hline Instructions and policies & 0.490 & 0.066 & 0.626 & 0.149 & 0.148 & 0.075 \\
\hline Communication within organization & 0.202 & 0.458 & 0.582 & 0.122 & 0.028 & 0.163 \\
\hline Co-workers' help & 0.002 & -0.026 & 0.199 & 0.838 & 0.072 & -0.009 \\
\hline Specialist help & 0.298 & 0.040 & 0.121 & 0.709 & 0.089 & 0.078 \\
\hline Guidelines & 0.109 & 0.360 & -0.052 & 0.544 & 0.240 & 0.077 \\
\hline Field computer or GPS & -0.032 & -0.013 & 0.120 & -0.068 & 0.792 & -0.019 \\
\hline GIS data & 0.201 & -0.004 & -0.001 & 0.185 & 0.755 & -0.042 \\
\hline Maps & 0.087 & 0.227 & 0.044 & 0.305 & 0.590 & 0.059 \\
\hline Time & 0.019 & 0.070 & 0.064 & 0.049 & -0.012 & 0.901 \\
\hline Financial resources & 0.124 & 0.123 & 0.126 & 0.047 & -0.004 & 0.880 \\
\hline
\end{tabular}


$\dagger$ Eigenvalues $>1$; varimax rotation with Kaiser normalization converged in six iterations.

Table A2-2. Princial component scores for information sourcing (scores $>0.5$ bolded). ${ }^{\dagger}$

\begin{tabular}{|c|c|c|c|c|}
\hline \multirow[b]{2}{*}{ Information sources } & \multicolumn{4}{|c|}{ Component } \\
\hline & Public agencies & Forestry operations & Internal & Forest administr \\
\hline $\begin{array}{l}\text { Percent variance } \\
\text { explained }\end{array}$ & 18.53 & 16.40 & 10.47 & 10.21 \\
\hline Regional council & 0.812 & 0.219 & -0.034 & -0.026 \\
\hline $\begin{array}{l}\text { Forestry Development } \\
\text { Centre Tapio }\end{array}$ & 0.816 & 0.251 & -0.045 & -0.014 \\
\hline $\begin{array}{l}\text { Finnish Environment } \\
\text { Institute }\end{array}$ & 0.716 & 0.057 & 0.219 & 0.039 \\
\hline Municipal zoning & 0.695 & 0.168 & 0.099 & 0.141 \\
\hline Land use register & 0.603 & 0.068 & 0.131 & 0.125 \\
\hline $\begin{array}{l}\text { Regional environment } \\
\text { centre }\end{array}$ & 0.572 & -0.016 & 0.219 & 0.330 \\
\hline Logging contractor & 0.133 & 0.729 & 0.167 & -0.164 \\
\hline $\begin{array}{l}\text { Own organization, } \\
\text { subordinates }\end{array}$ & 0.119 & 0.684 & 0.326 & -0.166 \\
\hline $\begin{array}{l}\text { Other forestry } \\
\text { professionals }\end{array}$ & 0.095 & 0.654 & 0.149 & 0.027 \\
\hline Timber buyer & 0.155 & 0.591 & 0.169 & -0.025 \\
\hline Forest owner & 0.118 & 0.570 & -0.079 & 0.288 \\
\hline $\begin{array}{l}\text { Local forest } \\
\text { management } \\
\text { association }\end{array}$ & 0.122 & 0.533 & 0.180 & 0.206 \\
\hline $\begin{array}{l}\text { Own organization, } \\
\text { nature specialist }\end{array}$ & 0.200 & 0.150 & 0.719 & 0.172 \\
\hline $\begin{array}{l}\text { Own organization, co- } \\
\text { worker }\end{array}$ & 0.012 & 0.420 & 0.657 & 0.250 \\
\hline $\begin{array}{l}\text { Own organization, } \\
\text { supervisor }\end{array}$ & 0.263 & 0.264 & 0.655 & 0.019 \\
\hline $\begin{array}{l}\text { Regional forestry } \\
\text { centre }\end{array}$ & 0.094 & 0.098 & 0.166 & 0.823 \\
\hline Inventory data & 0.215 & -0.131 & 0.234 & 0.748 \\
\hline
\end{tabular}




\begin{tabular}{lllll}
\hline Forest plan & 0.046 & 0.532 & -0.217 & $\mathbf{0 . 5 2 8}$ \\
Nature NGO & 0.499 & 0.069 & 0.363 & 0.062 \\
\hline
\end{tabular}

$\dagger$ Eigenvalues $>1$; varimax rotation with Kaiser normalization converged in seven iterations. 


\section{APPENDIX 3. DESCRIPTIVE STATISTICS OF COMPETENCIES}

Table A3-1. Descriptive statistics of human capital.

\begin{tabular}{lccc}
\hline \hline Human capital & Mean & Mode & SD \\
\hline Education, scale 0-4 & 2.10 & 2.00 & 0.72 \\
$\begin{array}{l}\text { Biodiversity training, scale 0- } \\
4\end{array}$ & 2.80 & 3.00 & 0.90 \\
$\begin{array}{l}\text { Experience, years in } \\
\text { profession }\end{array}$ & 20.39 & 21.00 & 10.12 \\
\hline
\end{tabular}

Table A3-2. Frequency of responses to organizational resource questions.

\begin{tabular}{|c|c|c|c|c|c|}
\hline \multirow[b]{2}{*}{$\begin{array}{l}\text { Organizational } \\
\text { resources }\end{array}$} & \multicolumn{2}{|c|}{$\begin{array}{c}\text { Currently } \\
\text { available (\%) }\end{array}$} & \multicolumn{3}{|c|}{$\begin{array}{l}\text { Development } \\
\text { in the future }(\%)\end{array}$} \\
\hline & Yes & No & Worsen & Stay same & Improve \\
\hline Training & 93 & 7 & 2 & 78 & 20 \\
\hline $\begin{array}{l}\text { Instructions and } \\
\text { policies }\end{array}$ & 95 & 5 & 1 & 78 & 21 \\
\hline $\begin{array}{l}\text { Guidelines for } \\
\text { exceptions/rare } \\
\text { situations }\end{array}$ & 82 & 18 & 1 & 76 & 23 \\
\hline $\begin{array}{l}\text { Information } \\
\text { management }\end{array}$ & 89 & 11 & 1 & 71 & 28 \\
\hline Documentation & 84 & 16 & 1 & 75 & 24 \\
\hline $\begin{array}{l}\text { Monitoring and } \\
\text { auditing }\end{array}$ & 80 & 20 & 2 & 76 & 22 \\
\hline $\begin{array}{l}\text { Continuous } \\
\text { improvement of } \\
\text { practices }\end{array}$ & 81 & 19 & 3 & 66 & 31 \\
\hline $\begin{array}{l}\text { Involvement of } \\
\text { workers in } \\
\text { developing } \\
\text { organizational } \\
\text { practices }\end{array}$ & 76 & 24 & 6 & 69 & 25 \\
\hline $\begin{array}{l}\text { Communication } \\
\text { within organization }\end{array}$ & 87 & 13 & 4 & 74 & 22 \\
\hline $\begin{array}{l}\text { Contact with } \\
\text { clients }\end{array}$ & 91 & 9 & 4 & 74 & 22 \\
\hline
\end{tabular}




\begin{tabular}{|c|c|c|c|c|c|}
\hline $\begin{array}{l}\text { Contact with } \\
\text { stakeholders }\end{array}$ & 91 & 9 & 3 & 76 & 21 \\
\hline $\begin{array}{l}\text { Field computer or } \\
\text { GPS }\end{array}$ & 62 & 38 & 0 & 50 & 50 \\
\hline Maps & 96 & 4 & 1 & 59 & 40 \\
\hline GIS data & 81 & 19 & 0 & 51 & 49 \\
\hline Guidelines & 92 & 8 & 1 & 79 & 20 \\
\hline Co-workers' help & 91 & 9 & 2 & 86 & 12 \\
\hline Specialist help & 83 & 17 & 3 & 82 & 15 \\
\hline Time & 72 & 28 & 33 & 62 & 5 \\
\hline Financial resources & 74 & 26 & 22 & 72 & 6 \\
\hline
\end{tabular}

Table A3-3. Descriptive statistics of information sourcing.

\begin{tabular}{llll}
\hline \hline Information sourcing & Mean & Mode & SD \\
\hline Inventory data & 1.85 & 0.00 & 1.45 \\
Forest plan & 2.25 & 3.00 & 1.20 \\
Forest owner & 1.51 & 2.00 & 1.17 \\
Regional forestry center & 2.23 & 3.00 & 1.38 \\
Regional environment center & 0.59 & 0.00 & 1.00 \\
Land use register & 0.22 & 0.00 & 0.59 \\
Municipal zoning & 0.25 & 0.00 & 0.56 \\
Regional council & 0.14 & 0.00 & 0.43 \\
Forestry Development Centre & 0.15 & 0.00 & 0.49 \\
Tapio & & 0.00 & 0.65 \\
Finnish Environment & 0.27 & 0.00 & 0.95 \\
Institute & & 0.00 & 1.20 \\
Own organization, supervisor & 0.55 & 0.00 & 1.14 \\
Own organization, co-worker & 1.35 & 0.00 & 1.00 \\
$\begin{array}{l}\text { Own organization, nature } \\
\text { specialist }\end{array}$ & 0.80 & & \\
Own organization, & 0.74 & & \\
subordinates & & & \\
& & & \\
\end{tabular}




\begin{tabular}{lccc}
\hline Other forestry professionals & 1.31 & 2.00 & 1.06 \\
$\begin{array}{l}\text { Local forest management } \\
\text { association }\end{array}$ & 1.66 & 0.00 & 1.41 \\
Timber buyer & 0.99 & 0.00 & 1.09 \\
Logging contractor & 1.10 & 0.00 & 1.06 \\
Nature NGO & 0.19 & 0.00 & 0.51 \\
\hline
\end{tabular}

